Contrasting Species-Specific, Compound-Specific, Seasonal, and Interannual Responses of Foliar Isoprenoid Emissions to Experimental Drought in a Mediterranean Shrubland Author(s): Joan Llusià, Josep Peñuelas, Giorgio A. Alessio, and Marc Estiarte Reviewed work(s):

Source: International Journal of Plant Sciences, Vol. 169, No. 5 (June 2008), pp. 637-645

Published by: The University of Chicago Press

Stable URL: http://www.jstor.org/stable/10.1086/533603

Accessed: $25 / 10 / 2012$ 08:27

Your use of the JSTOR archive indicates your acceptance of the Terms \& Conditions of Use, available at http://www.jstor.org/page/info/about/policies/terms.jsp

JSTOR is a not-for-profit service that helps scholars, researchers, and students discover, use, and build upon a wide range of content in a trusted digital archive. We use information technology and tools to increase productivity and facilitate new forms of scholarship. For more information about JSTOR, please contact support@jstor.org. 
Int. J. Plant Sci. 169(5):637-645. 2008.

(c) 2008 by The University of Chicago. All rights reserved.

1058-5893/2008/16905-0006\$15.00 DOI: $10.1086 / 533603$

\title{
CONTRASTING SPECIES-SPECIFIC, COMPOUND-SPECIFIC, SEASONAL, AND INTERANNUAL RESPONSES OF FOLIAR ISOPRENOID EMISSIONS TO EXPERIMENTAL DROUGHT IN A MEDITERRANEAN SHRUBLAND
}

\author{
Joan Llusià, ${ }^{1}$ Josep Peñuelas, Giorgio A. Alessio, and Marc Estiarte \\ Unitat d'Ecofisiologia Consejo Superior de Investigaciones Científicas-Centre d'Estudis Avançats de \\ Blanes-Centre de Recerca Ecològica i Aplicacions Forestals, Edifici C, Universitat \\ Autònoma de Barcelona, E-08193 Bellaterra, Catalonia, Spain
}

\begin{abstract}
We aimed to test the effect of soil drought conditions projected by general circulation models and ecophysiological models for the next few decades on emission rates of isoprenoids by Mediterranean shrublands. We conducted a field experiment in which we generated soil drought (ca. 12\%-20\% decreased soil moisture) using automatically sliding curtains, and we measured foliar isoprenoid emissions in the three dominant species of the studied shrubland (Erica multiflora L., Globularia alypum L., and Pinus halepensis L.) in two different annual periods. Monoterpene emissions were detected in the three studied species, but isoprene emissions were significantly detected only in E. multiflora. Main volatile terpenes emitted by the three species were $\alpha$-pinene, $\beta$-myrcene, limonene, and $\Delta^{3}$-carene. In general, maximum isoprenoid emission rates were found in the hottest periods, and minimum emission rates were found in winter. Isoprene emissions in E. multiflora ranged between practically $0 \mu \mathrm{g} \mathrm{g}^{-1}$ (dry matter) $\mathrm{h}^{-1}$ in winter 2005 and $57 \mu \mathrm{g} \mathrm{g}^{-1}$ (dry matter) $\mathrm{h}^{-1}$ in summer 2003. Isoprene emissions were $75 \%$ lower during the dry second annual period, 2004-2005, than during the first year, 20032004. In E. multiflora, there was an overall decrease of $19 \%$ in isoprene emissions in response to soil drought. Conversely, monoterpene emissions increased by $26.4 \%$ in drought treatment. In G. alypum, there was an overall increase of $75 \%$ in terpene emissions in response to soil drought. In P. halepensis, drought treatment increased terpene emission rates by $156 \%$. Drought treatment affected the emissions mainly in the hottest seasons, spring and summer. There were strong compound-specific, species-specific, interannual, and seasonal changes in the emission rates and in their response to the treatments. These data might help to improve prediction algorithms, inventories, and modeling of isoprenoid emissions and of their response to climate change (decreased isoprene emissions and increased monoterpene emissions under moderate or short-term drought and decreased emissions under severe or long-term drought), but the great variability highlights the difficulty of the task.
\end{abstract}

Keywords: emission rates, isoprene, terpenes, Mediterranean shrublands, climate change, soil drought, Erica multiflora, Globularia alypum, Pinus halepensis.

\section{Introduction}

In line with global temperatures, those of the Mediterranean region have risen in the last few decades and have been accompanied by increasing drought (Piñol et al. 1998; Peñuelas et al. 2002). It is probable that the warmer and drier weather and the droughts will persist in the near future (Sabaté et al. 2002; Peñuelas et al. 2005a; IPCC 2007), with the possibility of them having significant effects on vegetation (Peñuelas and Filella 2001; Peñuelas et al. 2002, 2005a; Peñuelas and Boada 2003), including changes in isoprenoid emission rates (Peñuelas and Llusià 2001, 2003).

Volatile isoprenoids are produced in many different plant tissues and physiological processes. Advances in molecular and genetic techniques and the development of new instrumentation for the collection and analysis of these volatile isoprenoids have increased our knowledge of their nature and function in recent years. In some plants, they accumulate in specialized organs in

${ }^{1}$ Author for correspondence; e-mail: j.llusia@creaf.uab.cat.

Manuscript received June 2007; revised manuscript received November 2007. leaves and stems and can be released as deterrents against pathogens and herbivores or to aid wound sealing after damage (Pichersky and Gershenzon 2002). In other plants, volatile isoprenoids are not stored but are emitted after production. They seem to serve to attract pollinators and herbivore predators and to communicate with other plants and organisms (Peñuelas et al. 1995; Shulaev et al. 1997). But there is another function of volatile isoprenoids that acquires further interest in light of current climate warming. Recently, evidence has emerged that the production and the emission of isoprenes and monoterpenes, which constitute a major fraction of biogenic volatile organic compounds, might confer some protection against high temperatures to the plant (Sharkey and Singsaas 1995; Singsaas 2000; Peñuelas and Llusià 2002; Copolovici et al. 2005; Peñuelas et al. 2005b) or even to the ecosystem (Peñuelas and Llusià 2003).

Plant isoprenoid emission rates are affected by water availability. Generally, they decrease in response to drought conditions (Gershenzon et al. 1978; Bertin and Staudt 1996; Peñuelas and Llusià 1997; Llusià and Peñuelas 1998; Brilli et al. 2007). They also respond to temperature (Seufert 1997; 
Llusià and Peñuelas 2000; Peñuelas and Llusià 2002, 2003) and seasonality (Yokouchi and Ambe 1984; Lerdau et al. 1995; Peñuelas and Llusià 1997; Llusià and Peñuelas 1998, 2000). Temperature rises increase the production and emission rates of most terpenes exponentially up to a maximum by enhancing the synthase enzyme activity, raising the terpene vapor pressure, and decreasing the resistance of emission pathways (Tingey et al. 1991; Loreto et al. 1996; Peñuelas and Llusià 2001).

However, the effects of soil drought on plant emission rates of isoprenoids are still not well known, and even less is known about the response of different species and different compounds under variable annual and seasonal conditions. Moreover, most studies have been conducted in laboratory conditions and on potted plants (Peñuelas and Llusià 1997, 2002; Llusià and Peñuelas 1998). In this study, we aimed to test the effect of soil drought projected by general circulation models and ecophysiological models (Sabaté et al. 2002; Peñuelas et al. 2005a; IPCC 2007) for the Mediterranean Basin in the coming decades on foliar isoprenoid emission rates. This was done over a period of $2 \mathrm{yr}$ of varying precipitation in field conditions. We studied three typical Mediterranean woody plants, the shrubs Erica multiflora L. (Ericaceae) and Globularia alypum L. (Globulariaceae) and the tree Pinus halepensis L. (Pinaceae), which are dominant in the studied Mediterranean shrubland. This shrubland is in succession toward a Mediterranean forest after a fire that occurred in 1994. We submitted the shrubland to an experimental soil drought of ca. $19 \%$ relative decrease of soil moisture generated by using automatically sliding curtains in the field (Beier et al. 2004; Peñuelas et al. 2004, 2007) throughout the four seasons of the two study years of contrasting precipitation.

\section{Table 1}

Annual and Seasonal Time Courses of Photosynthetic Rates and Stomatal Conductance for the Three Studied Species

\begin{tabular}{|c|c|c|c|c|c|}
\hline & $\begin{array}{l}\text { Photosynthetic } \\
\text { rates } \\
\left(\mu \mathrm{mol} \mathrm{m}^{-2} \mathrm{~s}^{-1}\right)\end{array}$ & $\begin{array}{c}\text { Stomatal } \\
\text { conductance } \\
\left(\mathrm{mol} \mathrm{m}^{-2} \mathrm{~s}^{-1}\right)\end{array}$ & & $\begin{array}{c}\text { Photosynthetic } \\
\text { rates } \\
\left(\mu \mathrm{mol} \mathrm{m}^{-2} \mathrm{~s}^{-1}\right)\end{array}$ & $\begin{array}{c}\text { Stomatal } \\
\text { conductance } \\
\left(\mathrm{mol} \mathrm{m}^{-2} \mathrm{~s}^{-1}\right)\end{array}$ \\
\hline Erica multiflora: & & & October 30, 2004: & & \\
\hline May 28, 2003: & & & Control & $3.02 \pm .44$ & $.04 \pm .01$ \\
\hline Control & $5.31 \pm .51$ & $.08 \pm .01$ & Drought & $3.08 \pm .25$ & $.04 \pm .01$ \\
\hline Drought & $6.15 \pm 1.31$ & $.09 \pm .02$ & February 3, 2005: & & \\
\hline August 19, 2003: & & & Control & $1.35 \pm .09$ & $.02 \pm .00$ \\
\hline Control & $2.20 \pm .69$ & $.03 \pm .01$ & Drought & $1.02 \pm .24$ & $.02 \pm .00$ \\
\hline Drought & $.67 \pm .04$ & $.06 \pm .02$ & May 25, 2005: & & \\
\hline November 13, 2003: & & & Control & $2.50 \pm .10$ & $.04 \pm .00^{\mathrm{A}}$ \\
\hline Control & $3.66 \pm .66$ & $.05 \pm .02$ & Drought & $4.01 \pm .89$ & $.01 \pm .00^{\mathrm{B}}$ \\
\hline Drought & $3.32 \pm .54$ & $.04 \pm .01$ & August 23, 2005: & & \\
\hline January $21,2004:$ & & & Control & $3.17 \pm .31$ & $.02 \pm .01^{\mathrm{A}}$ \\
\hline Control & $1.89 \pm .69$ & $.02 \pm .00$ & Drought & $5.32 \pm 1.22$ & $.06 \pm .01^{\mathrm{B}}$ \\
\hline Drought & $2.36 \pm .69$ & $.02 \pm .00$ & Pinus halepensis: & & \\
\hline October 30, 2004: & & & May 30, 2003: & & \\
\hline Control & $.53 \pm .14^{\mathrm{A}}$ & $.02 \pm .01$ & Control & $18.65 \pm 1.41$ & $.29 \pm .02^{\mathrm{A}}$ \\
\hline Drought & $1.14 \pm .07^{\mathrm{B}}$ & $.02 \pm .01$ & Drought & $12.75 \pm 1.77$ & $.17 \pm .04^{\mathrm{B}}$ \\
\hline February 3, 2005: & & & August 21, 2003: & & \\
\hline Control & $.73 \pm .03^{\mathrm{A}}$ & $.02 \pm .01$ & Control & $1.34 \pm .16$ & $.03 \pm .01$ \\
\hline Drought & $.46 \pm .12^{\mathrm{B}}$ & $.01 \pm .01$ & Drought & $1.28 \pm .11$ & $.02 \pm .00$ \\
\hline May 25, 2005: & & & November 15, 2003: & & \\
\hline Control & $1.12 \pm .04^{\mathrm{A}}$ & $.02 \pm .01$ & Control & $5.99 \pm .15$ & $.07 \pm .01$ \\
\hline Drought & $.63 \pm .08^{\mathrm{B}}$ & $.02 \pm .01$ & Drought & $5.95 \pm .26$ & $.05 \pm .01$ \\
\hline August 23, 2005: & & & January $23,2004:$ & & \\
\hline Control & $1.26 \pm .29$ & $.02 \pm .01$ & Control & $5.74 \pm .57$ & $.07 \pm .01$ \\
\hline Drought & $2.71 \pm .66$ & $.01 \pm .01$ & Drought & $5.75 \pm .65$ & $.06 \pm .01$ \\
\hline Globularia alypum: & & & November 9, 2004: & & \\
\hline May 28, 2003: & & & Control & $2.72 \pm .48^{\mathrm{A}}$ & $.03 \pm .01$ \\
\hline Control & $7.41 \pm .72$ & $.13 \pm .01$ & Drought & $.51 \pm .15^{\mathrm{B}}$ & $.01 \pm .01$ \\
\hline Drought & $10.03 \pm 1.83$ & $.16 \pm .02$ & February 4, 2005: & & \\
\hline August 19, 2003: & & & Control & $2.62 \pm .08^{\mathrm{A}}$ & $.02 \pm .00$ \\
\hline Control & $2.43 \pm .06$ & $.06 \pm .01$ & Drought & $.79 \pm .35^{\mathrm{B}}$ & $.03 \pm .01$ \\
\hline Drought & $2.63 \pm .41$ & $.07 \pm .02$ & May 26, 2005: & & \\
\hline November 13, 2003: & & & Control & $.26 \pm .19$ & $.01 \pm .00$ \\
\hline Control & $5.82 \pm 1.39$ & $.08 \pm .02$ & Drought & $.25 \pm .03$ & $.00 \pm .00$ \\
\hline Drought & $6.92 \pm 1.19$ & $.11 \pm .01$ & August 24, 2005: & & \\
\hline January $21,2004:$ & & & Control & $1.24 \pm .53$ & $.02 \pm .01$ \\
\hline Control & $3.14 \pm .51^{\mathrm{A}}$ & $.03 \pm .01^{\mathrm{A}}$ & Drought & $2.68 \pm .18$ & $.02 \pm .00$ \\
\hline Drought & $4.83 \pm .15^{\mathrm{B}}$ & $.05 \pm .01^{\mathrm{B}}$ & & & \\
\hline
\end{tabular}

Note. Different letters indicate significant differences between treatments $(P<0.05 ; n=3)$. 


\section{Material and Methods}

\section{Study Site and Species Description}

The study was carried out in a dry shrubland (RosmarinoEricion) at Garraf Natural Park in Catalonia, northeast Spain $\left(41^{\circ} 18^{\prime} \mathrm{N}, 1^{\circ} 49^{\prime} \mathrm{E}\right)$, at $210 \mathrm{~m}$ asl on a south-southeast slope $\left(13^{\circ}\right)$. The climate is typical Mediterranean (average annual temperature $15.1^{\circ} \mathrm{C}$ and average annual precipitation $455 \mathrm{~mm}$ ). The site, which is located on terraces of abandoned vineyards, suffered large-scale fires in the summers of 1982 and 1994. The soil is a petrocalcic calcixerept (Soil Survey Staff 1998), thin $(12-37 \mathrm{~cm})$ and with a loamy texture and abundant calcareous nodules. Currently, the regenerating vegetation covers $60 \%-70 \%$, with a maximum height of $70 \mathrm{~cm}$. The dominant species at the study site-Erica multiflora L., Globularia alypum L., Pinus halepensis L., Rosmarinus officinalis L., and the less abundant Pistacia lentiscus L.-are evergreen species that typically occur on basic soils of the western Mediterranean Basin, where they are common components of the coastal shrubland.

\section{Experimental System}

Extended summer soil drought was induced by covering the natural vegetation and soil with transparent, waterproof plastic curtains (ca. $20 \mathrm{~cm}$ above vegetation maximum height;
Beier et al. 2004; Peñuelas et al. 2004) during all rain events over the two growing seasons, from March to May and from October to December. During the period when the soil drought treatment was operating, rain sensors activated the curtains, covering the plants and soil whenever it rained and removing the curtains when the rain stopped.

Six plots of $20 \mathrm{~m}^{2}(4 \mathrm{~m} \times 5 \mathrm{~m})$ were established in the study site: three untreated controls and three soil drought plots. Control plots had scaffolding similar to that of soil drought plots but with no curtain. All the study plots were open around the edges. The outer $0.5 \mathrm{~m}$ of each study plot was considered a buffer zone, and all the measurements were conducted in the central $16-\mathrm{m}^{2}$ area.

Precipitation was measured at the study site with a standard rain gauge. Inside each study plot, one to three rain gauges placed above the height of the vegetation recorded the water input to each plot. Soil moisture was measured every 1-2 wk throughout the study period using time domain reflectometry. At each sampling date, volumetric water concentration at $0-15$ $\mathrm{cm}$ was estimated on three fixed sampling points per plot using a cable tester (1502B, Tektronix, Beaverton, OR). Air (20 $\mathrm{cm}$ aboveground) and soil $(5 \mathrm{~cm}$ depth) temperatures were obtained using temperature sensors RTD Pt100 1/3 DIN (Design Instruments, Barcelona) located in open areas of the two treatments (control and drought). Sensors were always protected against solar radiation. Temperatures were measured

Table 2

Annual and Seasonal Time Courses of Total Monoterpene, $\alpha$-Pinene, $\beta$-Pinene, $\beta$-Myrcene, $\Delta^{3}$-Carene, and Limonene Emission Rates $\left(\mu \mathrm{g} \mathrm{g}^{-1}\right.$ [d.m.] $\left.\mathrm{h}^{-1}\right)$ in Erica multiflora in Control and Drought Treatments

\begin{tabular}{|c|c|c|c|c|c|c|}
\hline & $\alpha$-Pinene & $\beta$-Pinene & $\beta$-Myrcene & $\Delta^{3}$-Carene & Limonene & Total terpenes \\
\hline \multicolumn{7}{|c|}{ May 28, 2003: } \\
\hline Control & $.54 \pm .31$ & nd & nd & $.23 \pm .14$ & $.01 \pm .00^{\mathrm{A}}$ & $.94 \pm .46$ \\
\hline Drought & nd & nd & nd & nd & $.11 \pm .11^{\mathrm{B}}$ & $.11 \pm .11$ \\
\hline \multicolumn{7}{|c|}{ August 19, 2003: } \\
\hline Control & $.26 \pm .02^{\mathrm{A}}$ & $.21 \pm .00$ & $.18 \pm .01$ & $.05 \pm .03$ & $.04 \pm .02$ & $2.29 \pm .44^{\mathrm{A}}$ \\
\hline Drought & $.04 \pm .00^{\mathrm{B}}$ & $.04 \pm .00$ & nd & $.02 \pm .01$ & $.14 \pm .04$ & $1.07 \pm .39^{\mathrm{B}}$ \\
\hline \multicolumn{7}{|c|}{ November 13, 2003: } \\
\hline Control & $.04 \pm .01^{\mathrm{A}}$ & $.01 \pm .00$ & $.06 \pm .03$ & $.01 \pm .00$ & nd & $.24 \pm .01^{\mathrm{A}}$ \\
\hline Drought & $.30 \pm .05^{\mathrm{B}}$ & $.05 \pm .18$ & $.06 \pm .06$ & $.01 \pm .00$ & nd & $.97 \pm .25^{\mathrm{B}}$ \\
\hline \multicolumn{7}{|c|}{ January 21, 2004: } \\
\hline Control & $.02 \pm .01^{\mathrm{A}}$ & nd & $.05 \pm .00$ & $.01 \pm .00$ & nd & $.98 \pm .54^{\mathrm{A}}$ \\
\hline Drought & $1.10 \pm .05^{\mathrm{B}}$ & $.31 \pm .00$ & $1.58 \pm .00$ & $.20 \pm .20$ & nd & $4.61 \pm 1.06^{\mathrm{B}}$ \\
\hline \multicolumn{7}{|c|}{ October 30, 2004: } \\
\hline Control & $.05 \pm .03$ & nd & nd & nd & $.76 \pm .44$ & $.81 \pm .41$ \\
\hline Drought & $.05 \pm .03$ & nd & nd & nd & $.03 \pm .01$ & $.36 \pm .14$ \\
\hline \multicolumn{7}{|c|}{ February 3, 2005: } \\
\hline Control & nd & nd & nd & nd & $.03 \pm .00^{\mathrm{A}}$ & $.04 \pm .01^{\mathrm{A}}$ \\
\hline Drought & nd & nd & nd & nd & $.23 \pm .04^{\mathrm{B}}$ & $.11 \pm .01^{\mathrm{B}}$ \\
\hline \multicolumn{7}{|c|}{ May 25, 2005: } \\
\hline Control & $.94 \pm .15$ & nd & $.01 \pm .00$ & nd & $.08 \pm .04$ & $1.67 \pm .09^{\mathrm{A}}$ \\
\hline Drought & $.63 \pm .32$ & nd & nd & nd & $.03 \pm .02$ & $2.12 \pm .05^{\mathrm{B}}$ \\
\hline \multicolumn{7}{|c|}{ August 23, 2005: } \\
\hline Control & $.04 \pm .02$ & nd & nd & nd & $.03 \pm .02$ & $.07 \pm .01^{\mathrm{A}}$ \\
\hline Drought & $.05 \pm .02$ & nd & nd & nd & $.00 \pm .00$ & $.03 \pm .01^{\mathrm{B}}$ \\
\hline
\end{tabular}

Note. Different letters indicate significant differences between treatments. Treatments in each particular season $(P<0.05 ; t$-test $)$. The statistical significances of the year, season, treatment factors, and their interactions (repeated-measures ANOVA) are as follows: for total monoterpenes: year, $P<0.001$; season, $P<0.01$; year $\times$ season, $P<0.001$; season $\times$ treatment, $P<0.001$; year $\times$ season $\times$ treatment, $P<0.001$. d.m. $=$ dry matter. nd $=$ not detected. 
every $10 \mathrm{~min}$, with the average of three measurements from each sensor being recorded.

\section{Sampling and Analysis of Plant Terpene and Other Isoprenoid Emissions}

From spring 2003 to winter 2003-2004 and from autumn 2004 to summer 2005 (fig. 2; tables 1-3), measurements were taken from one individual twig of each of the studied species in each of the six plots. Measurements were conducted sequentially from 0800 to 1600 hours solar time in order to measure different treatments at similar times of the day and thus avoid as far as possible the confounding effects of diurnal cycles on emission rates. Measurements were taken on sunny days, and PPFD values inside the measuring chamber ranged between 900 and $1200 \mu \mathrm{mol} \mathrm{m}{ }^{-2} \mathrm{~s}^{-1}$. Chamber temperature was allowed to fluctuate with the environment. Twigs were carefully handled to minimize measurement disturbance, and the system was allowed to stabilize for ca. 20 min before gas exchange measurements. Immediately after gas exchange and terpene sampling, the twigs were cut and stored in a portable refrigerator at $4^{\circ} \mathrm{C}$. Leaf area was measured in the laboratory using an LI-3100 area meter (LI-COR, Lincoln, NE).

Terpene sampling was conducted using a calibrated IRGA porometer (LCA-4, ADC, Hoddeson, Hertfordshire). Air leaving the cuvette flowed through a $\mathrm{T}$ system to a glass tube $(8 \mathrm{~cm}$ long and $0.3 \mathrm{~cm}$ internal diameter) manually filled with terpene adsorbents Carbopack B, Carboxen 1003, and Carbopack Y (Supelco, Bellefonte, PA) separated by plugs of quartz wool. Samples were taken using a Qmax air sampling pump (Supelco). The hydrophobic properties of the tubes were supposed to minimize sample displacement by water. In these tubes, terpenes did not suffer chemical transformations, as checked with standards $(\alpha$-pinene, $\beta$-pinene, camphene, myrcene, $p$-cymene, limonene, sabinene, camphor, and dodecane). Before use, these tubes were conditioned for $10 \mathrm{~min}$ at $350^{\circ} \mathrm{C}$ with a stream of purified helium. The sampling time was $5 \mathrm{~min}$, and the flow varied between 470 and $500 \mathrm{~mL}$ $\min ^{-1}$, depending on the tubes' adsorbent and quartz wool packing. A calibrated air sampling pump was used to trap isoprenoids. The trapping and desorption efficiency of liquid and volatilized standards such as $\alpha$-pinene, $\beta$-pinene, or limonene was practically $100 \%$. In order to eliminate the problem of memory effect of previous samples, blanks of 5-min air sampling without plants were carried out immediately before and after each measurement. The glass tubes were stored in a portable refrigerator at $4^{\circ} \mathrm{C}$ and taken to the laboratory, where they were stored at $-28^{\circ} \mathrm{C}$ until analysis (within 24$48 \mathrm{~h}$ ). There were no observable changes in terpene concentrations after storage of the tubes, as checked by analyzing replicate samples immediately and after 48 -h storage. Emission rate calculations were made on mass balance basis and by subtracting the control values (without plants) from the values of samples with plants. Flowers were not removed

Table 3

Annual and Seasonal Time Courses of Total Monoterpene, $\alpha$-Pinene, $\beta$-Pinene, $\beta$-Myrcene, $\Delta^{3}$-Carene, and Limonene Emission Rates $\left(\mu \mathrm{g} \mathrm{g}^{-1}\right.$ [d.m.] $\left.\mathrm{h}^{-1}\right)$ in Globularia alypum in Control and Drought Treatments

\begin{tabular}{|c|c|c|c|c|c|c|}
\hline & $\alpha$-Pinene & $\beta$-Pinene & $\beta$-Myrcene & $\Delta^{3}$-Carene & Limonene & Total terpenes \\
\hline \multicolumn{7}{|c|}{ May 28, 2003: } \\
\hline Control & $.14 \pm .08$ & nd & $.03 \pm .02$ & $.03 \pm .02$ & $.19 \pm .11$ & $.49 \pm .25$ \\
\hline Drought & $.11 \pm .06$ & nd & $.01 \pm .01$ & nd & $.04 \pm .02$ & $.19 \pm .10$ \\
\hline \multicolumn{7}{|c|}{ August 19, 2003: } \\
\hline Control & $.02 \pm .01$ & nd & nd & $.01 \pm .00 \mathrm{a}$ & $.02 \pm .01^{\mathrm{A}}$ & $.96 \pm .46$ \\
\hline Drought & nd & $.04 \pm .02$ & nd & nd & $.31 \pm .07^{\mathrm{B}}$ & $.93 \pm .23$ \\
\hline \multicolumn{7}{|c|}{ November 13, 2003: } \\
\hline Control & $.08 \pm .00^{\mathrm{A}}$ & nd & $.07 \pm .00$ & $.04 \pm .00$ & nd & $.43 \pm .05^{\mathrm{A}}$ \\
\hline Drought & $.03 \pm .01^{\mathrm{B}}$ & $.16 \pm .01$ & $.12 \pm .07$ & $.04 \pm .02$ & nd & $.85 \pm .10^{\mathrm{B}}$ \\
\hline \multicolumn{7}{|c|}{ January 21, 2004: } \\
\hline Control & nd & nd & nd & nd & nd & nd \\
\hline Drought & nd & $.03 \pm .03$ & nd & nd & nd & $.03 \pm .03$ \\
\hline \multicolumn{7}{|c|}{ October 30, 2004: } \\
\hline Control & $.04 \pm .04$ & nd & nd & nd & $.33 \pm .26$ & $1.71 \pm .64^{\mathrm{A}}$ \\
\hline Drought & $.03 \pm .03$ & nd & nd & nd & $.14 \pm .13$ & $.37 \pm .06^{\mathrm{B}}$ \\
\hline \multicolumn{7}{|c|}{ February 3, 2005: } \\
\hline Control & nd & nd & nd & nd & $.64 \pm .27$ & $.91 \pm .03^{\mathrm{A}}$ \\
\hline Drought & nd & nd & nd & nd & $.82 \pm .43$ & $2.15 \pm .04^{\mathrm{B}}$ \\
\hline \multicolumn{7}{|c|}{ May 25, 2005: } \\
\hline Control & $.98 \pm .72^{\mathrm{A}}$ & nd & nd & nd & $.02 \pm .02$ & $.81 \pm .37^{\mathrm{A}}$ \\
\hline Drought & $2.31 \pm .38^{\mathrm{B}}$ & nd & $1.44 \pm 1.44$ & nd & $1.66 \pm 1.13$ & $5.81 \pm 1.49^{\mathrm{B}}$ \\
\hline \multicolumn{7}{|c|}{ August 23, 2005: } \\
\hline Control & $.10 \pm .04$ & nd & nd & nd & $.02 \pm .01$ & $.08 \pm .00^{\mathrm{A}}$ \\
\hline Drought & $.07 \pm .07$ & nd & $.02 \pm .02$ & nd & $.02 \pm .02$ & $.21 \pm .06^{\mathrm{B}}$ \\
\hline
\end{tabular}

Note. Different letters indicate significant differences between treatments. Treatments in each particular season $(P<0.05 ; t$-test). The statistical significances of the year, season, treatment factors, and their interactions (repeated-measures ANOVA) are as follows: for total monoterpenes: year, $P<0.01$; season, $P<0.1$; treatment, $P<0.01$; year $\times$ season, $P<0.01$; year $\times$ treatment, $P<0.01$; season $\times$ treatment, $P<0.001$; year $\times$ season $\times$ treatment, $P<0.001$. d.m. $=$ dry matter. $n d=$ not detected. 
when present (in autumn and winter in E. multiflora and G. alypum).

Isoprenoid analyses were performed by using a GC-MS system (Hewlett Packard HP59822B, Palo Alto, CA). Trapped emitted monoterpenes were injected automatically by a robotic sample processor (FOCUS; ATAS GL International, Veldhoven, Netherlands) in an OPTIC3 injector (ATAS GL International) for $5 \mathrm{~min}$ and passed into a $30 \mathrm{~m} \times 0.25 \mathrm{~mm} \times 0.25 \mathrm{~mm}$ film
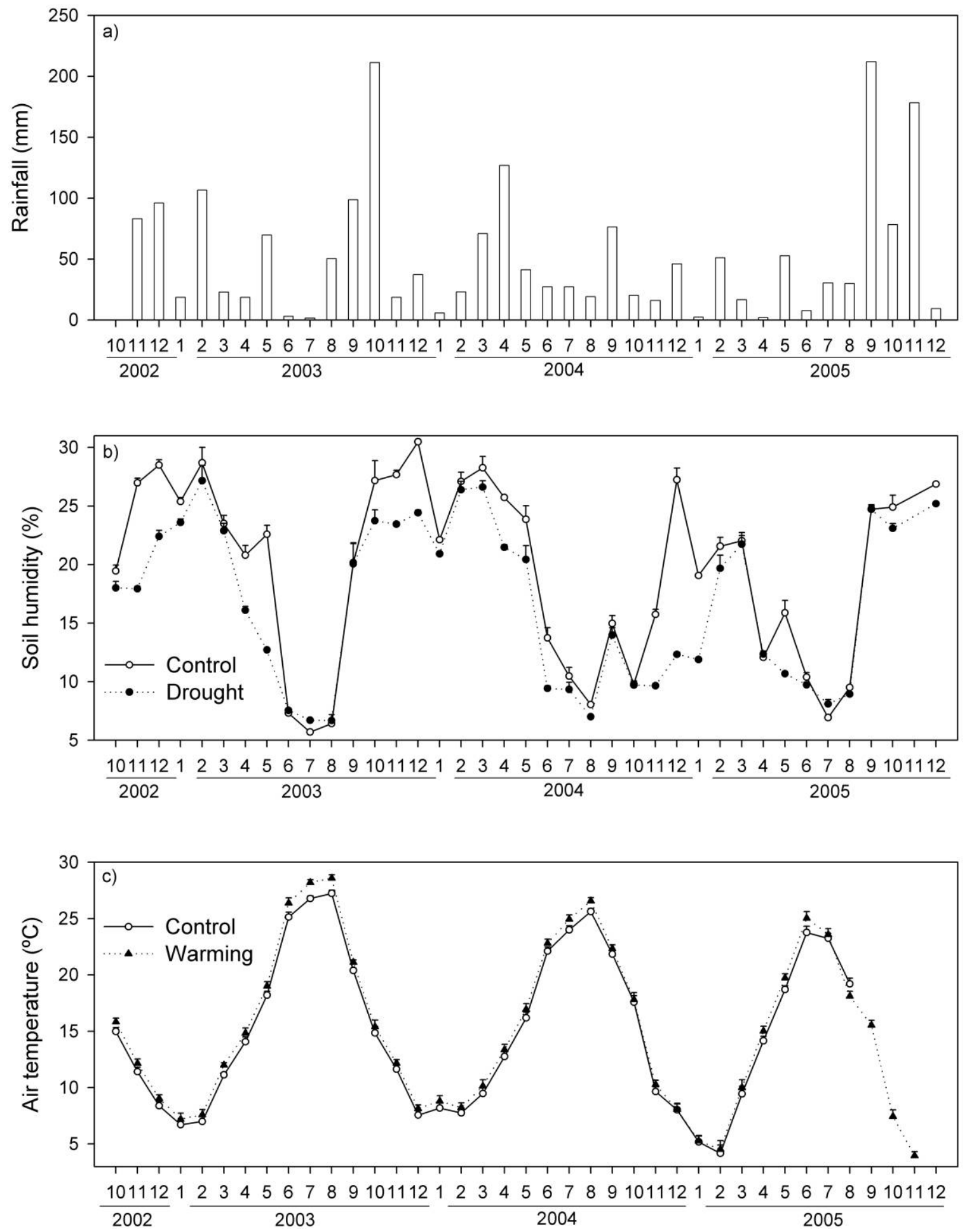

Fig. 1 Time courses of $(a)$ precipitation $(\mathrm{mm}),(b)$ soil moisture $(\% ; \mathrm{v} / \mathrm{v})$, and $(c)$ daily mean air temperature $\left({ }^{\circ} \mathrm{C}\right.$ during the period of the study, measured $20 \mathrm{~cm}$ above the soil). 
thickness capillary column (Supelco HP-5, Crosslinked 5\% Me Silicone, Supelco). After sample injection, the initial temperature $\left(40^{\circ} \mathrm{C}\right)$ was increased at $30^{\circ} \mathrm{C} \mathrm{min}^{-1}$ up to $60^{\circ} \mathrm{C}$ and then at $10^{\circ} \mathrm{C} \mathrm{m^{-1 }}$ up to $150^{\circ} \mathrm{C}$, maintained for $3 \mathrm{~min}$, and thereafter at $70^{\circ} \mathrm{C} \min ^{-1}$ up to $250^{\circ} \mathrm{C}$, which was maintained for another $5 \mathrm{~min}$. Helium flow was $0.7 \mathrm{~mL} \mathrm{~min}^{-1}$. The identification of monoterpenes was conducted by GC-MS and comparison with standards from Fluka (Buchs, Switzerland), literature spectra, and GCD Chemstation G1074A HP. Frequent calibration with common terpenes $\alpha$-pinene, $\Delta^{3}$-carene, $\beta$-pinene, $\beta$-myrcene, $p$-cymene, limonene, and sabinene standards once every five analyses was used for quantification. Terpene calibration curves $(n=4$ different terpene concentrations) were always highly significant $\left(r^{2}>0.99\right)$ in the relationship between signal and terpene emission rates. The most abundant terpenes had very similar sensitivity (differences were less than $5 \%$ ).

\section{Statistical Analyses}

Repeated-measures ANOVAs were conducted using STATISTICA (ver. 6.0 for Windows; StatSoft, Tulsa, OK). Statistical differences between treatments on each date were also analyzed following a $t$-Student test. Differences were considered significant at a probability level of $P<0.05$.

\section{Results}

\section{Soil Humidity, Precipitation, and Air Temperature}

Figure 1 shows the precipitation, soil moisture, and air temperature over the two sampling periods (2003-2004 and 2004-2005) in the studied area for the two different treatments. Soil humidity ranged between $4.7 \%(\mathrm{v} / \mathrm{v})$ in summer 2003 and $36.4 \%(\mathrm{v} / \mathrm{v})$ in winter 2003-2004. It rained more in the first sampling period than in the second (607.6 vs. 350.4 $\mathrm{mm})$. The soil drought treatment decreased soil moisture by an average of $12.4 \%$ and $19.7 \%$ relative to control soils in 2003-2004 and 2004-2005, respectively. Mean daily air temperature ranged between $0.35^{\circ} \mathrm{C}$ in winter and $29.3^{\circ} \mathrm{C}$ in summer. The warming treatment increased the temperatures by $0.7^{\circ} \mathrm{C}$ throughout the year in the air (fig. 1). The temperature increase persisted for most of the daytime, disappearing for a few hours only in the afternoon-evening before the dawn (Beier et al. 2004).

\section{Photosynthetic Rates and Stomatal Conductances}

Table 1 shows the photosynthetic rates and stomatal conductances of the three studied species. Maximum photosynthetic rates values were recorded in May 2003 (18.65 \pm 1.41 , $10.03 \pm 1.83$, and $6.15 \pm 1.31 \mu \mathrm{mol} \mathrm{m} \mathrm{m}^{-2} \mathrm{~s}^{-1}$ for Pinus halepensis, Globularia alypum and Erica multiflora, respectively) and minimum values in August $2003(-0.63 \pm 0.30)$ in $E$. multiflora. In general, no clear and consistent effects were found for the different treatments throughout the seasons, although there was a trend to decrease with drought treatment (table 1). Similar to the photosynthetic rates, stomatal conductances were maximum in May 2003 (0.29 \pm 0.02 , $0.16 \pm 0.02$, and $0.09 \pm 0.02 \mathrm{~mol} \mathrm{~m}^{-2} \mathrm{~s}^{-1}$ for P. halepensis,
G. alypum, and E. multiflora, respectively), and no consistent differences appeared between treatments, although again there was a general trend to decrease with drought treatment (table 1).

\section{Isoprenoid Emission Rates, Seasonal Patterns, and Responses to Soil Drought}

Isoprene was the main compound emitted by E. multiflora, and values ranged between practically $0 \mu \mathrm{g} \mathrm{g}^{-1}$ (dry matter [d.m.]) $\mathrm{h}^{-1}$ in winter 2005 and $57 \mu \mathrm{g} \mathrm{g}^{-1}$ (d.m.) $\mathrm{h}^{-1}$ in summer 2003 (fig. 2). Isoprene emissions decreased in the drier year (2004-2005), in the coldest seasons (autumn and winter), and with the drought treatment (fig. 2). The emissions of isoprene responded negatively to drought treatment in spring 2003 and in summer 2003 (fig. 2). Drought treatment decreased isoprene emissions by $35.2 \%$ in the first year and by $2.8 \%$ in the already dry second year. Overall, there was thus a $19 \%$ decrease in isoprene emissions in response to soil drought.

The three studied species emitted volatile terpenes. They emitted mostly $\alpha$-pinene, $\beta$-pinene, $\beta$-myrcene, $\Delta^{3}$-carene, and limonene (tables $2-4$ ). In general, maximum emission rates were observed in the hottest periods, with minimum emission rates occurring in the winter.

The monoterpene emission of E. multiflora ranged between $0.03 \mu \mathrm{g} \mathrm{g}^{-1}$ (d.m.) $\mathrm{h}^{-1}$ in autumn 2003 and $4.6 \mu \mathrm{g} \mathrm{g}^{-1}$ (d.m.) $\mathrm{h}^{-1}$ in winter 2003-2004 (table 2). Terpene emissions increased in the warmest seasons (spring and summer; table 2). The soil drought treatment increased total monoterpene emission rates of E. multiflora in autumn 2003, winter 20032004, winter 2005, and spring 2005 and decreased them in the other season (table 2). Monoterpene emissions showed an

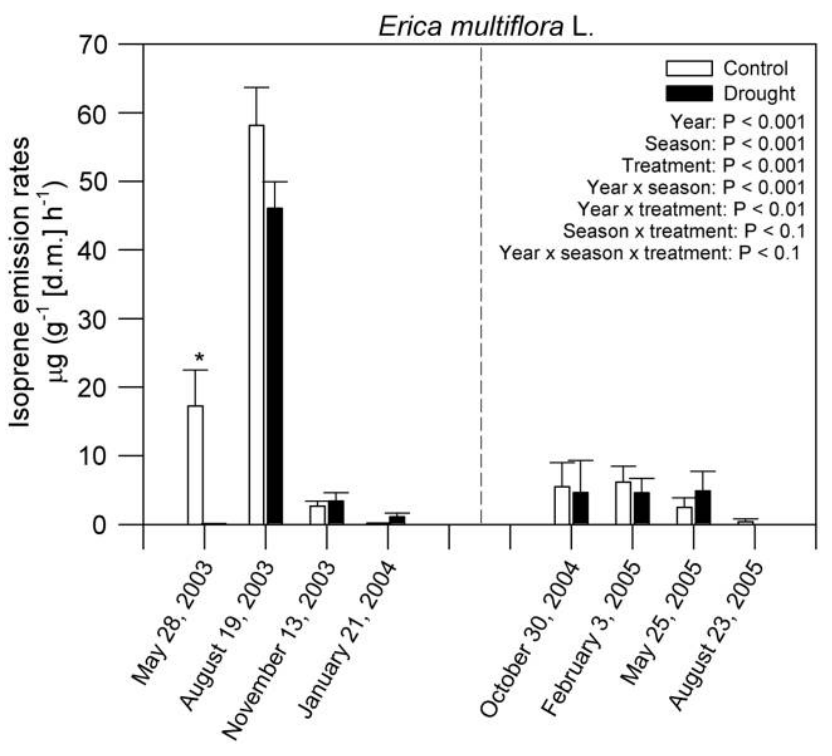

Fig. 2 Annual and seasonal time courses of isoprene emission rates in Erica multiflora in control and drought treatments (asterisk indicates $t$-test, $P<0.05$; treatment effect in each particular season). The statistical significance of the year, season, treatment factors, and their interactions (ANOVA) is depicted. 
Table 4

\begin{tabular}{|c|c|c|c|c|c|c|}
\hline & $\alpha$-Pinene & $\beta$-Pinene & $\beta$-Myrcene & $\Delta^{3}$-Carene & Limonene & Total terpenes \\
\hline \multicolumn{7}{|c|}{ May 28, 2003: } \\
\hline Control & $.34 \pm .11$ & nd & nd & nd & $.33 \pm .19$ & $.67 \pm .28$ \\
\hline Drought & $1.42 \pm .82$ & nd & nd & nd & $.07 \pm .02$ & $1.49 \pm .81$ \\
\hline \multicolumn{7}{|c|}{ August 19, 2003: } \\
\hline Control & $11.57 \pm .17^{\mathrm{A}}$ & $2.56 \pm .30$ & $16.62 \pm 4.85^{\mathrm{A}}$ & $8.00 \pm 1.49^{\mathrm{A}}$ & $.65 \pm .08$ & $41.30 \pm 8.06^{\mathrm{A}}$ \\
\hline Drought & $85.21 \pm 11.43^{\mathrm{B}}$ & $2.60 \pm .18$ & $40.88 \pm 5.25^{\mathrm{B}}$ & $12.31 \pm 2.29^{\mathrm{B}}$ & $.85 \pm .16$ & $147.78 \pm 18.64^{\mathrm{B}}$ \\
\hline \multicolumn{7}{|c|}{ November 13, 2003: } \\
\hline Control & $.17 \pm .03$ & $.03 \pm .02^{\mathrm{A}}$ & $.50 \pm .24$ & $.03 \pm .02$ & nd & $1.07 \pm .30$ \\
\hline Drought & $.91 \pm .43$ & $.07 \pm .01^{\mathrm{B}}$ & $1.81 \pm .85$ & $.03 \pm .01$ & nd & $2.96 \pm 1.38$ \\
\hline \multicolumn{7}{|c|}{ January $21,2004:$} \\
\hline Control & $.08 \pm .01^{\mathrm{A}}$ & $.20 \pm .09$ & $.05 \pm .01^{\mathrm{A}}$ & $.10 \pm .04$ & $1.99 \pm .24$ & $2.60 \pm .34$ \\
\hline Drought & $.24 \pm .02^{\mathrm{B}}$ & $.10 \pm .01$ & $.09 \pm .01^{\mathrm{B}}$ & $.14 \pm .03$ & $1.35 \pm .31$ & $1.98 \pm .31$ \\
\hline \multicolumn{7}{|c|}{ May 25, 2005: } \\
\hline Control & nd & $1.06 \pm 1.06$ & nd & nd & $.13 \pm .13$ & $1.29 \pm 1.29$ \\
\hline Drought & $1.03 \pm 1.03$ & nd & $.52 \pm .52$ & nd & $10.55 \pm 1.55$ & $63.97 \pm 4.72$ \\
\hline \multicolumn{7}{|c|}{ August 23, 2005: } \\
\hline Control & $1.44 \pm 1.01$ & nd & $2.83 \pm 2.63$ & $2.17 \pm 2.01$ & $.53 \pm .27$ & $7.41 \pm 6.20$ \\
\hline Drought & $3.20 \pm 2.30$ & nd & $3.91 \pm 2.08$ & $2.42 \pm 1.37$ & $1.20 \pm .96$ & $12.60 \pm 6.98$ \\
\hline $\begin{array}{l}\text { October 30, 2004: } \\
\text { Control }\end{array}$ & & & & & & \\
\hline \multicolumn{7}{|c|}{ February 3, 2005: } \\
\hline Control & $2.94 \pm .18^{\mathrm{A}}$ & $.57 \pm .10^{\mathrm{A}}$ & $.20 \pm .11$ & nd & $.77 \pm .14^{\mathrm{A}}$ & $32.44 \pm 9.72^{\mathrm{A}}$ \\
\hline Drought & $1.03 \pm .16^{\mathrm{B}}$ & $.20 \pm .04^{\mathrm{B}}$ & $.05 \pm .01$ & nd & $.33 \pm .06^{\mathrm{B}}$ & $11.06 \pm 1.87^{\mathrm{B}}$ \\
\hline
\end{tabular}

Note. Different letters indicate significant differences between treatments. Treatments in each particular season $(P<0.05 ; t$-test $)$. The statistical significance of the year, season, treatment factors, and their interactions (repeated-measures ANOVA) is as follows: for total monoterpenes: treatment, $P<0.001$; season, $P<0.001$; treatment $\times$ season, $P<0.001$. nd $=$ not detected.

overall increase of $26.4 \%$ in drought treatment. Individually detected monoterpenes followed the same pattern as that for total volatile organic compound emissions. The most emitted monoterpene was $\beta$-myrcene in the drought treatment in winter 2003-2004 (table 2).

The terpene emissions in G. alypum ranged between 0.005 $\mu \mathrm{g} \mathrm{g}^{-1}$ (d.m.) $\mathrm{h}^{-1}$ in winter 2003-2004 and $5.8 \mu \mathrm{g} \mathrm{g}^{-1}$ (d.m.) $\mathrm{h}^{-1}$ in spring 2005 (table 3 ). In this species, the emissions also increased in spring-summer and in response to drought treatment. Soil drought increased G. alypum emission rates of monoterpenes in autumn 2003, winter 2004-2005, and spring and summer 2005. There was an overall increase in terpene emissions of $75 \%$ in response to soil drought. The most emitted monoterpenes were $\alpha$-pinene, $\beta$-myrcene, and limonene in drought treatment in spring 2005.

The emissions in P. halepensis ranged between $0.55 \mu \mathrm{g} \mathrm{g}^{-1}$ (d.m.) $\mathrm{h}^{-1}$ in autumn 2003 and an exceptionally high 147.8 $\mu \mathrm{g} \mathrm{g}^{-1}$ (d.m.) $\mathrm{h}^{-1}$ in summer 2003 (table 4). In this species, the emissions also increased in spring-summer seasons and in response to drought treatment (table 4). Drought treatment significantly increased monoterpene emission rates in $P$. halepensis in summer 2003. In soil drought treatment, the increase for the first year was more than $238 \%$ and for the second year more than $95 \%$. Individually detected monoterpenes followed the same pattern as that for total monoterpene emissions. The most emitted monoterpenes were $\alpha$-pinene and $\beta$-myrcene in drought treatment in summer 2003 and in spring 2005 (table 4).

\section{Discussion}

The emission of isoprenoids was species specific (Llusià and Peñuelas 2000; Peñuelas and Llusià 2001). The greatest emissions were found in Pinus halepensis, followed by Erica multiflora (including isoprene and monoterpene emissions) and Globularia alypum (tables 2-4). The emission rates measured in $P$. halepensis were similar to those measured in the spring-summer season in one previous study (Llusià and Peñuelas 1998) but higher than values reported in another study in field conditions (Llusià and Peñuelas 2000). Our results (emission rates for isoprene between 0.1 and $57 \mu \mathrm{g} \mathrm{g}^{-1}$ [d.m.] $\mathrm{h}^{-1}$ and for monoterpenes around $4.6 \mu \mathrm{g} \mathrm{g}^{-1}$ [d.m.] $\mathrm{h}^{-1}$ ) also agree with those found by Owen et al. (1997) for E. multiflora.

The emissions followed a seasonal pattern in the three studied species. This pattern agrees with previous results obtained for isoprenoid emissions in most Mediterranean species that have their maximum in the spring-summer period and their minimum in cold seasons (Llusià and Peñuelas 2000). Similar to the other studied isoprenoids (tables 2-4), isoprene was released into the atmosphere mostly in the driest and hottest period (fig. 2). This seasonality is due to isoprenoid synthesis being dependent on temperature (Tingey et al. 1980; Llusià and Peñuelas 1999; Peñuelas and Llusià 1999a, 2001), light (Tingey et al. 1991; Langenheim 1994; Loreto et al. 1996; Peñuelas and Llusià 1999b), water availability (Bertin and 
Staudt 1996; Peñuelas and Llusià 1997; Llusià and Peñuelas 1998), and also phenology (Peñuelas and Llusià 1997; Llusià and Peñuelas 2000). The isoprene and monoterpene emissions observed in the warmest and driest seasons may play a protective role against excess temperature and drought (Sharkey and Singsaas 1995; Peñuelas and Llusià 2002; Copolovici et al. 2005; Llusià et al. 2005; Peñuelas et al. 2005b) and also against excessive solar radiation (Peñuelas and Munné-Bosch 2005) and oxidative stress in general (Loreto et al. 2004).

In the first period of the study (from spring 2003 to winter 2003-2004), isoprene emissions were much higher than in the drier second period (from autumn 2004 to summer 2005). Isoprene emission rates also decreased in response to the drought treatment (fig. 2). Conversely, foliar terpene emissions increased in response to drought treatment in the three speciesE. multiflora, G. alypum, and P. halepensis-and were also higher in the warmer year, 2003. It is widely reported that drought can decrease terpene emission rates (Llusià and Peñuelas 1998; Delfine et al. 2005). Water stress may reduce photosynthetic activity temporarily because of the increased resistance to $\mathrm{CO}_{2}$ in both the stomata and the mesophyll (Schulze and Hall 1982; Peñuelas et al. 1998; Centritto et al. 2003; Ogaya and Peñuelas 2003). This reduced photosynthetic activity, when it is severe, seems to drive a reduction of the emission rates (Llusià and Peñuelas 1998; Staudt et al. 2002; Plaza et al. 2005; Rennenberg et al. 2006; Brilli et al. 2007). Nevertheless, we did not find consistent differences in photosynthetic activity between the control and drought treatments. The differences depended on the season and the species and were not consistently related to the changes in emission rates. We found increases in emission rates, supporting the idea that drought can lead to increased formation of secondary metabolites (Vallat et al. 2005). The reduced stomatal conductance in the drought treatment may have led to increased leaf temperatures and the consequent increased monoterpene emissions. However, the difference in leaf temperatures was not signifi- cant. Further studies are needed to corroborate these results and to disentangle the possible effects of several factors affecting the changes in emission rates, such as phenological phases like flowering (Llusià and Peñuelas 2000) or the possible interaction with warming-induced dark respiration, for example, a competition for substrates such as reported by Rosenstiel et al. (2003). The severity of the drought may also greatly influence the emission levels, with increases occurring under moderate drought - probably having a role in increased drought and heat stress tolerance (Peñuelas and Llusià 2001, 2002)—and decreases occurring under severe drought (Llusià and Peñuelas 1998; Peñuelas and Llusià 2001, 2003; Brilli et al. 2007).

The improvement in knowledge of species-specific, compoundspecific, seasonal, and interannual isoprenoid emissions and their responses to drought will help in the study of prediction algorithms, inventories, and modeling of monoterpene and isoprene emissions. However, the results of this study show a great species-specific, compound-specific, seasonal, and interannual variance in isoprenoid emissions that is due to the complexity of factors driving these emissions (Peñuelas and Llusià 2001). This variance is accompanied by a great species-specific, compoundspecific, seasonal, and interannual variance in volatile isoprenoid content reported in these same species (Llusià et al. 2006). Altogether, this makes the prediction of the response to increasing soil drought not an easy task.

\section{Acknowledgments}

Our research was partly supported by ISONET (Marie Curie network contract MC-RTN-CT-2003 504720) from the European Union, grants CGL2004-01402/BOS and CGL200604025/BOS from the Spanish government, a 2004 grant from the Fundación BBVA, a European Union grant (ALARM contract 506675), and a SGR2005-00312 grant from the Catalan government.

\section{Literature Cited}

$\rightarrow$ Beier C, B Emmett, P Gundersen, A Tietema, J Peñuelas, M Estiarte, C Gordon, et al 2004 Novel approaches to study climate change effects on terrestrial ecosystems in the field: drought and passive nighttime warming. Ecosystems 7:583-597.

$\rightarrow$ Bertin N, M Staudt 1996 Effect of water stress on monoterpene emission from young potted holm oak (Quercus ilex L.) trees. Oecologia 107:456-462.

$\rightarrow$ Brilli F, C Barta, A Fortunati, M Lerdau, F Loreto, M Centritto 2007 Response of isoprene emission and carbon metabolism to drought in white poplar (Populus alba) saplings. New Phytol 175:244-254.

$\rightarrow$ Centritto M, F Loreto, K Chartzoulakis 2003 The use of low $\left[\mathrm{CO}_{2}\right]$ to estimate diffusional and non-diffusional limitations of photosynthetic capacity of salt-stressed olive saplings. Plant Cell Environ 26: 585-594.

$\rightarrow$ Copolovici L, I Filella, J Llusià, U Niinemets, J Peñuelas 2005 The capacity for thermal protection of photosynthetic electron transport varies for different monoterpenes in Quercus ilex. Plant Physiol 139:485-496.

$\rightarrow$ Delfine S, F Loreto, P Pinelli, R Tognetti, A Alvino 2005 Isoprenoids content and photosynthetic limitations in rosemary and spearmint plants under water stress. Agric Ecosyst Environ 106:243-252.

$\rightarrow$ Gershenzon J, DE Lincoln, JH Langenheim 1978 The effect of mois- ture stress on monoterpenoid yield and composition in Satureja douglasii. Biochem Syst Ecol 6:33-43.

IPCC (Intergovernmental Panel on Climate Change) 2007 Climate change 2007-the physical science basis: Working Group 1 contribution to the Fourth Assessment Report of the IPCC. Cambridge University Press, Cambridge.

$\rightarrow$ Langenheim JH 1994 Higher plant terpenoids: a phytocentric overview of their ecological roles. J Chem Ecol 20:1223-1280.

$\rightarrow$ Lerdau M, P Matson, R Fall, RK Monson 1995 Ecological controls over monoterpene emissions from Douglas fir (Pseudotsuga menziesii). Ecology 76:2640-2647.

$\rightarrow$ Llusià J, J Peñuelas 1998 Changes in terpene concentration and emission in potted Mediterranean woody plants under increasing drought. Can J Bot 76:1366-1373.

1999 Pinus halepensis and Quercus ilex terpene emission rates as affected by temperature and humidity. Biol Plant 42:317-320.

2000 Seasonal patterns of terpene content and emission from seven Mediterranean woody species in field conditions. Am J Bot 87:133-140.

$\rightarrow$ Llusià J, J Peñuelas, GA Alessio, M Estiarte 2006 Seasonal contrasting changes of foliar concentrations of terpenes and other volatile organic compounds in four dominant species of a Mediterranean 
shrubland submitted to a field experimental drought and warming. Physiol Plant 127:632-649.

$\rightarrow$ Llusià J, J Peñuelas, D Asensio, S Munné-Bosch 2005 Airborne limonene confers limited thermotolerance to Quercus ilex. Physiol Plant 123:40-48.

Loreto F, P Ciccioli, A Cecinato, E Brancaleoni, M Frattoni, D Tricoli 1996 Influence of environmental factors and air composition on the emission of $\alpha$-pinene from Quercus ilex leaves. Plant Physiol 110: 267-275.

Loreto F, P Pinelli, F Manes, H Kollist 2004 Impact of ozone on monoterpene emissions and evidence for an isoprene-like antioxidant action of monoterpenes emitted by Quercus ilex leaves. Tree Physiol 24:361-367.

Ogaya R, J Peñuelas 2003 Comparative seasonal gas exchange and chlorophyll fluorescence of two dominant woody species in a holm oak forest. Flora 198:132-141.

$\rightarrow$ Owen S, C Boissard, RA Street, SC Duckham, O Csiky, CN Hewitt 1997 Screening of 18 Mediterranean plant species for volatile organic compound emissions. Atmos Environ 31:101-117.

$\rightarrow$ Peñuelas J, M Boada 2003 A global change-induced biome shift in the Montseny Mountains (NE Spain). Global Change Biol 9:131-140.

$\rightarrow$ Peñuelas J, I Filella 2001 Phenology: responses to a warming world. Science 294:793-795.

$\rightarrow$ Peñuelas J, I Filella, P Comas 2002 Changed plant and animal life cycles from 1952 to 2000 in the Mediterranean region. Global Change Biol 8:531-544.

$\rightarrow$ Peñuelas J, I Filella, J Llusià, D Siscart, J Piñol 1998 Comparative field study of spring and summer leaf gas exchange and photobiology of the Mediterranean trees Quercus ilex and Phillyrea latifolia. J Exp Bot 49:229-238.

Peñuelas J, I Filella, S Sabate, C Gracia 2005a Natural systems: terrestrial ecosystems. Pages 517-553 in JE Llebot, ed. Report on climate change in Catalonia. Institut d'Estudis Catalans, Barcelona.

Peñuelas J, C Gordon, L Llorens, T Nielsen, A Tietema, C Beier, P Bruna, B Emmett, M Estiarte, A Gorissen 2004 Nonintrusive field experiments show different plant responses to warming and drought among sites, seasons and species in a north-south European gradient. Ecosystems 7:598-612.

$\rightarrow$ Peñuelas J, J Llusià 1997 Effects on carbon dioxide and seasonality on terpene concentration and emission by Rosmarinus officinalis $\mathrm{L}$. J Chem Ecol 23:979-994.

$\rightarrow-1999 a$ Seasonal emission of monoterpenes by the Mediterranean tree Quercus ilex in field conditions: relations with photosynthetic rates, temperature and volatility. Physiol Plant 105:641-647.

$\rightarrow-1999 b$ Short-term responses of terpene emission rates to experimental changes of PFD in Pinus halepensis and Quercus ilex in summer field conditions. Environ Exp Bot 42:61-68.

$\rightarrow-2001$ The complexity of factors driving volatile organic compound emissions by plants. Biol Plant 44:481-487.

$\rightarrow \quad 2002$ Linking photorespiration, monoterpenes and thermotolerance in Quercus. New Phytol 155:227-237.

$\rightarrow-2003$ BVOCs: plant defense against climate warming? Trends Plant Sci 8:105-109.

$\rightarrow$ Peñuelas J, J Llusià, D Asensio, S Munné-Bosch 2005b Linking isoprene with plant thermotolerance, antioxidants and monoterpene emissions. Plant Cell Environ 28:278-286.

$\rightarrow$ Peñuelas J, J Llusià, M Estiarte 1995 Terpenoids: a plant language. Trends Ecol Evol 10:289.

$\rightarrow$ Peñuelas J, S Munné-Bosch 2005 Isoprenoids: an evolutionary pool for photoprotection. Trends Plant Sci 10:166-169.
Peñuelas J, P Prieto, C Beier, C Cesaraccio, P De Angelis, G de Dato, BA Emmett, et al 2007 Response of plant species richness and primary productivity in shrublands along a north-south gradient in Europe to seven years of experimental warming and drought: reductions in primary productivity in the heat and drought year of 2003. Global Change Biol 13:2563-2581.

$\rightarrow$ Pichersky E, J Gershenzon 2002 The formation and function of plant volatiles: perfumes for pollinator attraction and defense. Curr Opin Plant Biol 5:237-243.

$\rightarrow$ Piñol J, J Terradas, F Lloret 1998 Climate warming, wildfire hazard and wildfire occurrence in coastal eastern Spain. Clim Change 38: 345-357.

$\rightarrow$ Plaza J, L Núñez, M Pujadas, R Pérez-Pastor, V Bermejo, S GarcíaAlonso, S Elvira 2005 Field monoterpene emission of Mediterranean oak (Quercus ilex) in the central Iberian Peninsula measured by enclosure and micrometeorological techniques: observation of drought stress effect. J Geophys Res 110:D03303, doi:10.1029/ 2004JD005168.

$\rightarrow$ Rennenberg H, F Loreto, A Polle, F Brilli, S Fares, RS Beniwal, A Gessler 2006 Physiological responses of forest trees to heat and drought. Plant Biol 8:556-571.

$\rightarrow$ Rosenstiel TN, MJ Potosnak, KL Griffin, R Fall, RK Monson 2003 Increased $\mathrm{CO}_{2}$ uncouples growth from isoprene emission in an agriforest ecosystem. Nature 6920:256-259.

$\rightarrow$ Sabaté S, C Gracia, A Sánchez 2002 Likely effects of climate change on growth of Quercus ilex, Pinus halepensis, Pinus pinaster, Pinus sylvestris and Fagus sylvatica forests in the Mediterranean region. For Ecol Manag 162:23-37.

Schulze ED, AE Hall 1982 Stomatal responses, water loss and $\mathrm{CO}_{2}$ assimilation rates of plants in contrasting environments. Pages 181-230 in OL Lange, PS Nobel, CB Osmond, H Ziegler, eds. Physiological plant ecology. II. Water relations and carbon assimilation. Springer, Berlin.

$\rightarrow$ Seufert G 1997 BEMA: a European commission project on biogenic emissions in the Mediterranean area. Atmos Environ 31:246.

$\rightarrow$ Sharkey TD, EL Singsaas 1995 Why plants emit isoprene. Nature 374:769.

$\rightarrow$ Shulaev V, P Silverman, I Raskin 1997 Airborne signalling by methyl salicylate in plant pathogen resistance. Nature 385: 718-721.

$\rightarrow$ Singsaas EL 2000 Terpenes and the thermotolerance of photosynthesis. New Phytol 146:1-4.

Soil Survey Staff 1998 Keys to soil taxonomy. USDA-Natural Resources Conservation Service, Washington, DC.

Staudt M, S Rambal, R Joffre 2002 Impact of drought on seasonal monoterpene emissions from Quercus ilex in southern France. J Geophys Res 107:4602, doi:10.1029/2001JD002043.

$\rightarrow$ Tingey DT, M Manning, LC Grothaus, WF Burns 1980 Influence of light and temperature on monoterpene emission rates from slash pine. Plant Physiol 65:797-801.

Tingey DT, DP Turner, JA Weber 1991 Factors controlling the emission of monoterpenes and other volatile organic compounds. Pages 93-120 in TD Sharkey, EA Holland, HA Mooney, eds. Trace gas emission by plants. Academic Press, San Diego, CA.

$\rightarrow$ Vallat A, H Gu, D Silvia 2005 How rainfall, relative humidity and temperature influence volatile emissions from apple trees in situ. Phytochemistry 66:1540-1550.

$\rightarrow$ Yokouchi Y, Y Ambe 1984 Factors affecting the emission of monoterpenes from red pine (Pinus densiflora). Plant Physiol 75:1009_ 1012. 